\title{
Improving Students' Toefl Listening Skill through Task-Based Learning Approach
}

\author{
Juliana \\ Department of Social Science \& Education, UniversitasPotensi Utama, Medan, Indonesia \\ juliana@potensi-utama.ac.id
}

\begin{abstract}
Toefl is urgently needed as an administrative requirement to work and participate in the scholarship competition. Students are required to master skills of this test. However, based on the results of pre-observations conducted in Information System class of Potensi Utama University, it is known that the average Toefl scores of students in Reading (37.8\%), structure (32.7\%), and Listening (29.5\%). This phenomenon occurs because Toefl learning emphasizes a lot of activities on reading and structure skills so students do not get listening tasks with good quality and quantity. Therefore, the effective learning approach is needed to make Toefl learning process more effective in improving the listening skill of students. The result showed that there was an Improving of students' listening skill from the test results of before observation with the highest conversion score of students' Toefl listening is 43. Meanwhile, after being given action and application of task-based learning approach there was a change that the highest score of students' Toefl listening in cycle I is 54 and the highest score of students' Toefl listening in cycle II is 62. Therefore, it can be concluded that using the task-based learning approach has significantly improved students' Toefl listening skill.
\end{abstract}

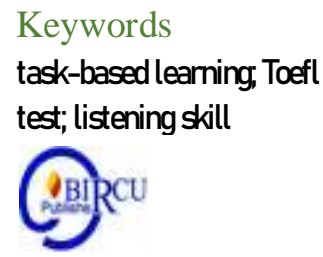

Keywords

task-based learning, Toefl test; listening skill

\section{Introduction}

One of the missions of Potensi Utama University is to create graduates who have competitiveness at the international level. Therefore, to achieve this program, students must have English language skills. One of the instruments to measure students' English skills is through test of English as a Foreign Language or better known as Toefl test. Students' Toefl test skill can be improved and tested through Toefl Preparation I, II and III courses for 3 related semesters and after taking Toefl classes, students must continue the learning process by taking the Toefl test to measure and evaluate students' Toefl ability. This is done to obtain a Toefl certificate as an administrative requirement to continue the next stage of study. Therefore, students of Potensi Utama University are required to be able to have knowledge and skills in this Toefl test.(J. Juliana, 2018)

However, based on the results of pre-observation conducted in the Information System class of Toefl Preparation I course, it is known that the ability of one of the skills tested on Toefl test is students' listening skill is still on average very low. Listening is one of the skills that is still considered difficult for students. Many students have difficulty to listen and understand this Toefl listening audio or dialogue, even though they have been learning English for many years. This is according to this article, which revealed that Listening comprehension ability is one of the most difficult ones to master, especially in an EFL context in which the students are not exposed to the natural speech of the native speakers and therefore are reluctant in attending listening classes [Rahbar \& Khodabakhsh, 2013]. 
Some of the difficulties that students often complain about they are not able to understand the dialogue text of audio Toefl listening, because they do not master the vocabulary conveyed by English native speakers in the audio. Secondly, they do not understand the meaning of Toefl listening dialogue delivered by native speakers. Thirdly, they do not know the efective strategy applied according to the question types and Fourth, the absence of appropriate learning method by involving students effectively in listening to audio text of Toefl listening. Similarly, students in English Language Education Study Program of Muhammadiyah Ponorogo University in listening ability for TOEFL Preparation courses, it is known that the listening skill of the average student is still very low. This is because Listening is an active activity that requires a high understanding and focus on what is heard, involving the experience and knowledge of the listener [Palupi, 2018]. In addition, the same thing also experienced by students of the Department of English Language and Literature, University of Negeri Semarang, showed that the results of students' Toefl listening are relatively not good [De Vega, 2018]. The average of students' Toefl listening score is 68.17 , with a low score of 44 and a high score of 84 with a range of values $0-100$. The results of the research also showed that students' Toefl listening score of University of Borneo is still less than the high score is at an average score of 7.68 with the lowest score obtained by students is 18 for the highest score is 68 and a maximum score of 100 . Therefore, an effective solution is needed to improve students' Toefl listening skill [Yulia Nur Ekawati, 2017].

As a solution to this problem is to apply an effective learning approach and support learning process in improving students' listening comprehension skills on Toefl test. One of the effective learning approaches is to use a task-based listening learning approach to implement strategies according to the problem [Jack C. Richards, 1983]. He explained the stages in implementing a task-based listening learning approach to implement strategies is a very simple and easy learning approach for students because it is applied according to existing problems consisting of (1) pre-tasks activities; (2) task activities; 3) post-task activities. From the approach of listening learning process based on this task is able to improve the listening skill of students, especially on Toefl listening (Juliana Juliana \& Amaniarsih, 2020).

TBLT starts with a task-based needs analysis to identify the target tasks for a particular group of learners - what they need to be able to do in the new language. In other words, task in TBLT has its normal, non-technical meaning. Tasks are the real-world activities people think of when planning, conducting, or recalling their day [Long, 2014]. In addition [Kuswoyo \& Wahyudin, 2017] with this approach, students are asked to listen to what are described as authentic situations and to do something with the information. Pedagogically, task-based language teaching has strengthened the following principles and practices such as a needs-based approach to content selection, an emphasis on learning to communicate through interaction in the target language, the introduction of authentic texts into the learning situation, the provision of opportunities for learners to focus not only on language but also on the learning process itself and an enhancement of the learner's own personal experiences as important contributing elements to classroom learning [David, 1991]. This approach makes it easy for students to learn independently in constructing real products naturally and enjoys the learning process supported by discussions in the classroom. So this can be applied as solution in solving problems that occur during Toefl classes, especially Toefl listening as an effort to improve students' listening skill in Toefl course [Purba, 2020]. 
Based on the background above, it can be stated that this research is important to be conducted (1) to make Toefl Listening learning process more effective for the students of Potensi Utama University through the use of task-based learning approach (2) to improve students' Toefl listening skill by applying the stages and strategies of using task-based learning approach. From the purpose of this research is expected to provide benefits (1) as a solution to improve Toefl listening skill of students and (2) as a reference in the development of the learning process for teachers who teach Toefl courses.

\section{Review of Literatures}

Toefl is better known as Test of English as a Foreign Language that a test to determine a person's proficiency in English. It is usually done as a pre-requisite to entry to campuses in United States or other countries in the world or also as a prerequisite for entering a world-class company. Usually this test takes about three hours and is conducted in 4 parts, namely: listening comprehension, grammar structure and written expression, reading comprehension, and writing section.

Listening in TOEFL is divided into three parts namely: (1) Short Dialogues, two lines of conversation followed by questions about the intent of the speaker (2) Long Conversation consists of 60-90 seconds of conversation about the world of student affairs followed by questions and (3) Talk or conversations about campus life and academic topics followed by a few questions. These listening skills work on the ability to absorb various component skills such as in Listening skills, students are trained to hear and capture language functions which are described in three groups, namely: (a). Structures for Restatements such as similar sounds, synonyms, homophones, negatives, negative emphasis, exclamations, references, causatives, correlatives conjunctions, comparatives, conditionals, concessions, causals, cause-and-result adjectives, tag questions, passives, chronological events; (b).Types of Conversations; direct conversations, computation conversation, place conversations and implied conversations; (c).Topics for Mini-Talks such as overheard conversations, announcements and advertisements, news reports, weather reports, information speeches, academic statements, class discussions. (Sari et al., 2019)

The Structure and Written Expression is similar as grammar which is the milestone of a language. Grammar learning is divided into various skills. This skill includes grammatical problems such as subjects and verbs; objects and prepositions; present participles; past participles; coordinate connectors; adverb clause connectors; noun clause connectors; noun clause connector/subjects; adjective clause connectors; adjective clause connectors/subjects; agreement after prepositional phrase; agreement agreement after expressions of quantity; agreement after certain words; parallel structure with coordinate conjunctions; parallel structure with pair conjunctions; past participles after have; present participles or past participles after be; base form verbs after modals; singular and plural nouns; countable and uncountable nouns; subject and object pronouns; possessives; pronoun reference; adjectives and adverbs; adjectives after linking verbs.

Reading skill discuses on how to understand: main idea questions; Stated detail questions; find unstated details; implied detail questions; vocabulary in context questions; 'Where' questions. All questions are given in multiple choice form with various discourse topics such as marine, space, biology topics, and cover almost all scientific topics. Students are required to master various scientific topics and be able to understand vocabulary for each discipline. The purpose of scientific exposure is because the aim of Toefl is to prepare high school graduates to continue their studies to a higher level both abroad and 
domestically [Phillips, 2001]. In general, it is recognized three levels of mastery of a foreign language, namely Elementary, Intermediate, and Advanced. for the TOEFL score, linguists usually classify this score into the following four levels: Elementary Level is ranged 310 until 420, Low Intermediate is ranged 420 until 480, High Intermediate is ranged 480 until 520 and Advanced Level (Advanced) is ranged 525 to 677 [Kostin, 2004].

TBLT attempts to make the connection between the internal, cognitive, and external, social dimensions of tasks in several ways. The first is by maintaining a clear distinction between target tasks and pedagogic tasks. The former represent the end-state, productoriented, expert view of what the learner needs to be able to do, the view sought from domain experts in a task-based learning. Some pedagogic tasks in TBLT do have a primarily internal, cognitive, "language acquisition" function, in that they are deliberately designed to increase the frequency of such phenomena as negative feedback and other negotiation work, more complex output, or the probability of learners detecting new linguistic features in the input. Moreover, many experimental studies of relationships among task-types and IL use have also employed the narrower, "cognitive-only" definition, in order to achieve the control an experiment requires. However, such cases are by no means the only forms pedagogic tasks can, and often do, take in materials design. Pedagogic tasks in TBLT are contextualized socially in a variety of ways, not least by invoking learners' knowledge of the world for their resolution and as indicated below, their reconceptualization.

The third and final way in which the cognitive and social dimensions of tasks are linked concerns TBLT's role in preparing students as agents of social change (emancipation being one of its underlying philosophical principles, for themselves, and potentially, for others. Steps are taken, both in pedagogic task design and in the area of methodology, to make learners aware of their potential as social actors, not merely passive observers, in determining task outcomes and, where necessary, in redefining tasks. Similarly, in addition to improving lecture comprehension strategies, pedagogic tasks in an EAP listening comprehension course may include work on such matters as culturally acceptable ways of interrupting speakers to elicit reruns of difficult sequences and to improve learners' efficient use of office-hour appointments, tutorials, teaching assistant (TA) sections, and study groups [Long, 2014]

\section{Research Methods}

\subsection{Research Methods}

The research approach is classroom action research. This research is structured to solve a problem, test in real situations by looking at flaws and strengths and make changes that serve as improvements. In this classroom action research, task-based learning approach is used in a particular class selected. In the implementation of this classroom action research, there are two instruments used namely observation to find out students' learning activities in Toefl listening classes and tests to find out the results of Toefl listening learning process. Aspects of observation are (a) the process of implementing the TBL learning approach, (b) the effect of both intentional and unintentional actions and (c) the constraints that impede the action. While the aspects of the test include the competency of listening skill according to Toefl Listening syllabus [Stringer, E. T., \& Aragón, 2020].

The subject of this study was a fifth semester students of Information Systems study program, Potensi Utama University. The population of fifth semester students is 365 students. Based on that population, researcher took only one class of 25 students as a sample of the study by using purposive sampling. This research instrument used one group 
pre-test and post-test. Samples of one predetermined class are pre-tested to find out their initial abilities, then after being treated using the TBL learning approach, in the final stage was given a post-test to find out the final ability after being taught using the TBL approach.

\subsection{Research Procedures}

The research procedures consist of 2 cycles. Each cycle is carried out in accordance with the changes to be achieved, as it has been designed in the variables investigated. To know the listening skills of the students, a diagnostic test is provided that serves as the initial evaluation. Preliminary observations are made to know the exact action given in order to minimize the error. From the evaluation and preliminary observation, it can be determined that the action was to improve students' listening skills is through the use of task-based learning approach. Based on the initial reflection, this classroom action research was carried out by (1) planning, (2) action implementation, (3) observation, and (4) reflection procedures in every cycle.

Planning was carried out to conduct CAR research, namely; develop learning tools such as Toefl syllabus, quiz of Toefl listening tasks, prepare learning media (recording, cassette, movie, power point), prepare learning strategies /steps using TBL, arrange instruments (Observation and Test), develop observation guidelines, develop Toefl Listening test results, and plan research schedule.

The implementation of this research action was to apply what is already planned on the action plan. The action of applying TBL learning approach and Toefl Listening material was done at this stage. At this stage, recording, processing, and interpretation of data analysis results on the process and products of the implementation of task-based learning approach to the learning process and listening skill of students.

The reflection stage describes the data analysis procedure, reflection with regard to the process in implementing the action that is implementation of task-based learning approach, the impact of corrective actions, criteria and plans in the next action. A data analysis technique used descriptive analysis. Meanwhile, to measure students' Toefl listening skill by using the average score system in the results of each cycle and activity. The criteria for research are success seen from the score data obtained from students' learning achievement. Data of students' learning achievement to listening skill before the action obtained from the pre-test is used to know the students' scores before the action is carried out and post-test data in cycle II to measure the extent of success after the action in cycle I. If the improvement of learning results in the final condition has not reached more than high intermediate level with 485 - 520 score then further action was taken in cycle II. The purpose of this follow-up was to improve Toefl listening learning process and overcome any obstacles and weaknesses found in the previous cycle.

\section{Results and Discussion}

\subsection{Description of Pre-Cycle Activities}

To find out the student's pre-cycle activities before applying task-based learning approach in Toefl listening skill, the researcher conducted a pre-observation. In this activity, students were asked to do Toefl listening test. This step is carried out to obtain preliminary information about the students' listening skills of information system, Potensi Utama University to Toefl listening test. 
Tabel 1. Students' Pre-Observation Scores of Toefl Listening Task

\begin{tabular}{|c|c|c|c|c|}
\hline No & Students' Initials & Correct Answer & Pre-Observation & Description \\
\hline 1 & ATW & 21 & 45 & Qualified \\
\hline 2 & MAP & 21 & 45 & Qualified \\
\hline 3 & AS & 21 & 45 & Qualified \\
\hline 4 & WMS & 20 & 45 & Qualified \\
\hline 5 & DP & 20 & 45 & Qualified \\
\hline 6 & TRN & 19 & 44 & Qualified \\
\hline 7 & DS & 19 & 44 & Qualified \\
\hline 8 & INR & 18 & 43 & Qualified \\
\hline 9 & LP & 18 & 43 & Qualified \\
\hline 10 & LA & 18 & 43 & Qualified \\
\hline 11 & NHF & 17 & 42 & Unqualified \\
\hline 12 & NAP & 17 & 42 & Unqualified \\
\hline 13 & OFESL & 16 & 41 & Unqualified \\
\hline 14 & EEJS & 16 & 41 & Unqualified \\
\hline 15 & DFP & 15 & 41 & Unqualified \\
\hline 16 & DAP & 14 & 39 & Unqualified \\
\hline 17 & EH & 13 & 38 & Unqualified \\
\hline 18 & HD & 12 & 37 & Unqualified \\
\hline 19 & EAM & 11 & 35 & Unqualified \\
\hline 20 & ASR & 11 & 35 & Unqualified \\
\hline 21 & KA & 10 & 33 & Unqualified \\
\hline 22 & JA & 10 & 33 & Unqualified \\
\hline 23 & RSM & 10 & 33 & Unqualified \\
\hline 24 & LI & 9 & 32 & Unqualified \\
\hline 25 & NA & 9 & & Unqualified \\
\hline
\end{tabular}

Based on the results of the conversion score [Phillips, 2001] it can be said that student's Toefl listening score before observation and application of task-based learning approach is at elementary level with 310-420 and lower level with 425 - 480. Preobservation results showed that there were 15 students $(60 \%)$ is unqualified and 10 students (40\%) is qualified with Toefl listening task. Because the results before observation have not met and still very low scores of qualified for Toefl listening for students, namely at the elementary level of $310-420$, it was deemed necessary to follow up on Cycle I, making an effort to improve students' Toefl listening skill, one of which was by applying task-based learning approach.

\subsection{Description of Cycle I Activities}

The cycles I and II consist of four stages are planning, implementation of actions, observation and evaluation, and reflection. Each cycle took 90 minutes. Here are the stages of each cycle's activities.

At the planning stage, it was done by creating and preparing learning tools such as lesson plans, quiz tasks in the form of Toefl listening exercises, learning media (recording, video, film, power point slide), learning strategies / steps using TBL, research instruments consisting of observation guidelines, pre-test and post-test Toefl Listening learning questions and results. In implementing the action, the teaching steps using the TBL approach are as follows. Firstly, Researcher as lecturer provided problems to students 
related to Toefl listening questions of academic topics. Secondly, Researcher organized students in several groups discussion. Thirdly, Researcher helped students organize the learning tasks of each member in their group according to the problems faced. Fourthly, Students gathered knowledge and conduct task about Toefl listening exercises in accordance with the problem solving provided. And the last, Students developed and presented Toefl listening learning results.

At next stage, it was done by observing and recording all students' activities in learning process using task-based learning approach. In addition, it also recorded the situation and condition of students when doing tests / tasks given. From the results of the task, then analyze the results of students' Toefl listening task. To avoid the element of subjectivity, in this study assisted by other observer by colleagues as lecturer of Toefl Preparation I to assess the activity. Assessment used conversion score by 4 levels scores on Toefl test with a minimum score of 310 [Phillips, 2001].

After observation and evaluation was done, and then reflect on the actions with the implementation of task-based learning approach that has been applied. At this stage, the evaluation results showed that the increase in students' learning achievement has not reached $71 \%$. Students still find it difficult to answer Toefl listening questions. Therefore, at the stage of reflection, the following steps are carried out. Firstly, Researchers gave more attention and encouragement to students to be more confident and enjoy in completing the tasks related to Toefl listening given. In this first cycle, students began to understand the stages in applying the TBL approach, but the test results given are not yet qualified. In terms of giving questions, researchers are careful when giving those questions starting from the easiest questions then the hardest questions. Tasks should also be varied and easy for students so that students are motivated to learn English easily and enjoyable. From the reflection of cycle I, it can be stated that the listening skill of the students to Toefl test shows an increase in the average score of students' learning results before taught using TBL as well as increased students' motivation and interest in learning. They were very enthusiastic to learn Toefl Listening. This can be seen from their interest in learning Toefl Listening using learning media such as audio recording, video, film, and power points.

Tabel 2. Students' Pre-Test Scores of Toefl Listening Task

\begin{tabular}{|c|c|c|c|c|c|c|c|}
\hline NO & $\begin{array}{c}\text { Students' } \\
\text { Initials }\end{array}$ & $\begin{array}{c}\text { Correct } \\
\text { Answer }\end{array}$ & $\begin{array}{c}\text { Pre-Test } \\
\text { Cycle I }\end{array}$ & Description & $\begin{array}{c}\text { Correct } \\
\text { Answer }\end{array}$ & $\begin{array}{c}\text { Pre-Test } \\
\text { Cycle II }\end{array}$ & Description \\
\hline 1 & ATW & 28 & 49 & Qualified & 31 & 51 & Qualified \\
\hline 2 & MAP & 27 & 48 & Qualified & 31 & 51 & Qualified \\
\hline 3 & AS & 27 & 48 & Qualified & 30 & 51 & Qualified \\
\hline 4 & WMS & 27 & 48 & Qualified & 30 & 51 & Qualified \\
\hline 5 & DP & 26 & 48 & Qualified & 29 & 50 & Qualified \\
\hline 6 & TRN & 26 & 48 & Qualified & 29 & 50 & Qualified \\
\hline 7 & DS & 26 & 48 & Qualified & 29 & 50 & Qualified \\
\hline 8 & INR & 25 & 48 & Qualified & 29 & 50 & Qualified \\
\hline 9 & LP & 25 & 48 & Qualified & 28 & 49 & Qualified \\
\hline 10 & LA & 25 & 48 & Qualified & 27 & 49 & Qualified \\
\hline 11 & NHF & 24 & 47 & Qualified & 26 & 48 & Unqualified \\
\hline 12 & NAP & 24 & 47 & Qualified & 25 & 48 & Unqualified \\
\hline 13 & OFESL & 23 & 47 & Qualified & 24 & 47 & Unqualified \\
\hline 14 & EEJS & 23 & 47 & Qualified & 24 & 47 & Unqualified \\
\hline
\end{tabular}




\begin{tabular}{|l|c|c|c|c|c|c|c|}
\hline 15 & DFP & 23 & 47 & Qualified & 24 & 47 & Unqualified \\
\hline 16 & DAP & 23 & 47 & Qualified & 24 & 47 & Unqualified \\
\hline 17 & EH & 22 & 46 & Qualified & 23 & 47 & Unqualified \\
\hline 18 & HD & 21 & 45 & Qualified & 22 & 46 & Unqualified \\
\hline 19 & EAM & 20 & 45 & Qualified & 22 & 46 & Unqualified \\
\hline 20 & ASR & 19 & 44 & Qualified & 22 & 46 & Unqualified \\
\hline 21 & KA & 18 & 43 & Qualified & $\mathbf{2 2}$ & 46 & Unqualified \\
\hline 22 & JA & 17 & 42 & Unqualified & 20 & 45 & Unqualified \\
\hline 23 & RSM & 17 & 42 & Unqualified & 20 & 45 & Unqualified \\
\hline 24 & LI & 17 & 42 & Unqualified & 20 & 45 & Unqualified \\
\hline 25 & NA & 17 & 42 & Unqualified & 20 & 45 & Unqualified \\
\hline
\end{tabular}

Based on the results of the pre-test score in cycle I and II, it can be said that students' learning results in cycle 1 increased at the high intermediate level or ranged scores 480-520 with the highest score of 49 and the lowest score of 42 in cycle 1 and the highest score of 51 and the lowest score of 45 in cycle II. In cycle I, students' learning results changed where students who were unqualified to 4 students $(16 \%)$ and qualified increased to 21 students $(84 \%)$ with ranged score 420 until 480 in the lower middle level.

Because the pre-test results in cycle I have not met qualified score for students' Toefl listening, namely at the high intermediate level with a score of 485 until 520, then the action is continued to cycle II with the hope that students' listening skill can improve significantly in accordance with the level of students' listening ability that is high intermediate level with a score range of 485 - 520. And students get and use strategies for solving the listening questions efectively. Researchers also improved the provision of tasks more varied, according to the problem, and interesting. The tasks given are gradual from easy to difficult according to the problems faced by students, so that students could easily complete the tasks given.

\subsection{Description of Cycle II Activities}

The Pre-tasks activities stage was carried out by delivering and teaching the materials of Toefl listening, preparing students for Toefl listening materials that are listened to and exploring as much knowledge or experience as possible related to the Toefl listening material studied. This includes an introduction to Toefl listening, parts of Toefl listening tested, and strategies applied to each section of Toefl listening including sections A, B and C. Wilson (2008) said that with the pre-tasks activities, students are able to do various listening exercises given at the tasks activities well and enjoy because at pre-tasks activities stage, students are introduced Toefl listening material according to the needs and problems that can enable schemata in predicting answers and applying strategies to answer questions in accordance with the material Toefl listening questions heard, so that the knowledge and experience they have at the pre-task activities stage can help to master new material taught.

Activities were carried out at the Pre-tasks activities include; (1) asking questions about Toefl listening, (2) discussing each parts of the question, (3) predicting the answers and strategies of Toefl listening, (4) recounting experiences relevant to the topic of Toefl listening taught, (5) exploring ideas or vocabulary related to the academic materials and topics of Toefl listening taught. With these activities, students focus their attention on one particular topic, so that students can connect knowledge or experience that has been possessed with the academic material of Toefl listening at the tasks activities stage. 
The second stage is the task-activities stage of students by predicting the information heard, and writing down the answers Toefl listening. At this stage, students listen to the audio text of Toefl listening that has been prepared in accordance with the learning plan. This stage is to help students understand the text they hear independently. In principle in the teaching of Toefl listening, when listening to audio text of Toefl listening, they do not need to understand the meaning of each word. They are directed to understand the information they hear in general or to understand specific information. Activities carried out at this stage of tasks-activities include; (1) doing tasks on Toefl listening in accordance with given problems such as practicing the conversation of Toefl listening dialogue part A, (2) directing students to work together in their groups and organizing the learning tasks of each member in the group in accordance with the problems discussed by asking to recount the information that has been heard in the Toefl listening section B and C. (3) Implementing strategies in solving Toefl listening exercises based on the problems in each of three parts of Toefl listening. For example, in part A Toefl listening short dialogue by implementing several strategies including focusing on the second speaker of the dialogue, it usually what is asked is on the second speaker's dialogue. Find synonyms: is similarity of the second speaker's words or ideas, avoid statements that sound and written the same on the answer options of the second speaker's conversational statement, and Try to find clues such as who, what, where, these are helpful keywords and also be the answer to the question. Some strategies to answer Toefl listening questions part B and C are Try to guess what the topic will be., Try to guess what the questions will be., Get the main idea from the first sentence or two., Listen for the answers in order. The material used for the taskactivities is authentic Toefl listening material taken from various sources such as the internet, and exercises from Deborah Philips in accordance with the syllabus. (4) Directing students to give responses, opinions, answers to discussion results and writing reports on group discussion results. (5) Presenting the results of the discussion to other students. After that, train independently by providing individual Toefl listening tasks. By presenting authentic materials of Toefl listening from various sources and apply strategies to answer Toefl listening questions according to the problem familiarize and help students understanding oral information about academic topics in the Toefl listening test with the real listening situation.

The last stage is post-task activities. At this stage students connected and applied between what they heard according to their own ideas or experiences such as gathering knowledge and doing exercises according to the problem solving that is understood. By carrying out three stages of teaching activities and learning Toefl listening, then what students expect from teaching listening skills can be realized.

The results of student activities related to Toefl listening skill on Toefl listening task in cycle II showed a significant improvement that there were only two unqualified students (4\%) with the correct number of questions about 25 questions and 23 other students (96\%) were qualified with the number of correct questions above 50 questions with an average score of 500 - 620. This reaches the standard Toefl level for students, namely high intermediate (485 - 520) and advanced level (525 - 677). The following is a table of Students' Post-Test Scores to Toefl Listening Task in Cycle I and II 
Tabel 3. Students' Post-Test Scores of Toefl Listening Task in Cycle I and II

\begin{tabular}{|c|c|c|c|c|c|c|c|}
\hline No & $\begin{array}{c}\text { Students' } \\
\text { Initials }\end{array}$ & $\begin{array}{c}\text { Pre- } \\
\text { Obervation }\end{array}$ & Description & $\begin{array}{c}\text { Post-Test } \\
\text { Cycle I }\end{array}$ & Description & $\begin{array}{c}\text { Post-Test } \\
\text { Cycle II }\end{array}$ & Description \\
\hline 1 & ATW & 45 & Qualified & 54 & Qualified & 62 & Qualified \\
\hline 2 & MAP & 45 & Qualified & 52 & Qualified & 62 & Qualified \\
\hline 3 & AS & 45 & Qualified & 52 & Qualified & 61 & Qualified \\
\hline 4 & WMS & 45 & Qualified & 52 & Qualified & 60 & Qualified \\
\hline 5 & DP & 45 & Qualified & 52 & Qualified & 59 & Qualified \\
\hline 6 & TRN & 44 & Qualified & 51 & Qualified & 59 & Qualified \\
\hline 7 & DS & 44 & Qualified & 51 & Qualified & 58 & Qualified \\
\hline 8 & INR & 43 & Qualified & 51 & Qualified & 57 & Qualified \\
\hline 9 & LP & 43 & Qualified & 51 & Qualified & 57 & Qualified \\
\hline 10 & LA & 43 & Qualified & 50 & Qualified & 56 & Qualified \\
\hline 11 & NHF & 42 & Unqualified & 50 & Qualified & 55 & Qualified \\
\hline 12 & NAP & 42 & Unqualified & 50 & Qualified & 54 & Qualified \\
\hline 13 & OFESL & 41 & Unqualified & 49 & Qualified & 54 & Qualified \\
\hline 14 & EEJS & 41 & Unqualified & 49 & Qualified & 53 & Qualified \\
\hline 15 & DFP & 41 & Unqualified & 49 & Qualified & 53 & Qualified \\
\hline 16 & DAP & 39 & Unqualified & 49 & Qualified & 52 & Qualified \\
\hline 17 & EH & 38 & Unqualified & 49 & Qualified & 52 & Qualified \\
\hline 18 & HD & 37 & Unqualified & 49 & Qualified & 51 & Qualified \\
\hline 19 & EAM & 35 & Unqualified & 49 & Qualified & 51 & Qualified \\
\hline 20 & ASR & 35 & Unqualified & 49 & Qualified & 50 & Qualified \\
\hline 21 & KA & 33 & Unqualified & 49 & Qualified & 50 & Qualified \\
\hline 22 & JA & 33 & Unqualified & 48 & Unqualified & 50 & Qualified \\
\hline 23 & RSM & 33 & Unqualified & 48 & Unqualified & 50 & Qualified \\
\hline 24 & LI & 32 & Unqualified & 48 & Unqualified & 48 & Unqualified \\
\hline 25 & NA & 32 & Unqualified & 48 & Unqualified & 48 & Unqualified \\
\hline TOTAL & 10 Qulified Students & 21 Qulified Students & 23 & Qulified Students \\
\hline
\end{tabular}

Table 3 above shows the results of students' post test score to Toefl listening test, Before treatment as many as 10 students are qualified, while after giving the action and implementation of task-based learning approach there is a change in post test scores in cycle I as many as 21 students are qualified and 23 students are qualified in cycle II, namely at the upper intermediate level (485 - 520) and advanced level (525 - 677).

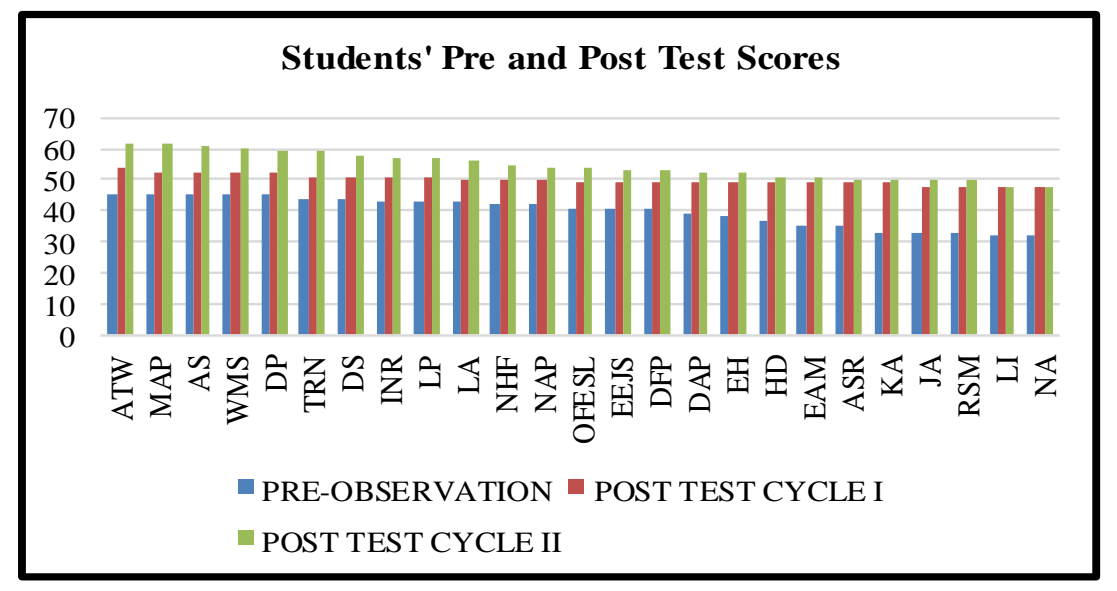

Figure 1. Students' Pre and Post Test Scores 
Based on the results of the average score of students' Toefl listening test in cycle I and cycle II In graph 1 showed that the average ability score of students on Toefl listening task has an improvement. The results of students' Toefl Listening test in both cycles showed that the average score of the number of correct answers generated on the Toefl Listening test before observation was 21 correct answers with the highest conversion score of 45 and 9 correct answers with the lowest conversion score of 32 . While the average score of the number of correct answers on Toefl Listening Task in cycle I was 36 correct answers with the highest score conversion of 54 and 26 correct answers with the lowest score of 48. And the average score of the number of correct answers on the Toefl Listening Task in cycle II was 45 correct answers with the highest conversion score of 62 and 25 correct answers with the lowest score of 48 . This means that in cycle II after the task-based learning approach was implemented, two students were unqualified as much as (4\%) with the number of correct answers about 25 questions, and 23 other students (96\%) were qualified with the number of correct answers above 50 questions with an average value of 500 - 620. This reaches the standard Toefl level for students, namely high intermediate (485 - 520) and advanced level (525 - 677). Therefore, it can be concluded that through Task-Based Learning approach, students' Toefl listening skill has increased significantly.

\section{Conclusion}

Based on the results and discussion, it can be concluded that task-based learning approach can be applied in Toefl Listening class. Task-based learning approach can improve students' confidence and the results of students' Toefl listening skill. The increase in student learning achievement was demonstrated through the average number of students' correct questions given on the Toefl Listening Task test in both cycles applied. Before treatment as many as 10 students are qualified, while after given action and application of task-based learning there is a change in post test scores in cycle I as many as 21 students are qualified and 23 students are qualified in cycle II, namely at the high intermediate level and advanced level.

The average number of correct questions generated on Toefl Listening Task test in the first cycle was 36 correct answers with the highest conversion score of 54 and 26 correct answers with the lowest score of 48. The average number of correct answers generated on the Toefl Listening Task test in cycle II was 45 correct answers with the highest conversion score of 62 and 25 correct answers with the lowest score of 48 . This shows two are unqualified students (4\%) with the number of correct answers about 25 questions and 23 other students (96\%) are qualified with the number of correct answers above 50 questions with an average value of 500 - 620. This reaches standard Toefl level for students, namely high intermediate (485 - 520) and advanced level (525 - 677). Therefore, it can be concluded that through the Task-Based Learning approach, students' Toefl listening ability has increased significantly. 


\section{References}

David, N. (1991). Language teaching methodology (Printice Hall (ed.); Printice H).

De Vega, N. (2018). Meningkatkan Skor Toefl Listening Mahasiswa Melalui Group Investigation Bagi Mahasiswa Semester Empat Jurusan Pendidikan Bahasa Inggris Universitas Borneo Tarakan. Jurnal Borneo Humaniora, 1(2), 1-5.

Jack C. Richards. (1983). Listening Comprehension: Approach, Design, Procedure. Tesol Quarterly, 17(2), 166-174. http://www.hpu.edu/Libraries_HPU/Files/TESOL/TQD/VOL_17_2.pdf\#page=57

Juliana, J. (2018). The Effect of Lexical Inferencing Strategies on Students' Reading Comprehension. Journal MELT (Medium for English Language Teaching), 1(2), 126-143.

Juliana, Juliana, \& Amaniarsih, D. S. (2020). Peningkatan Pengetahuan dan Pemahaman Siswa SMA Nurul Hasanah terhadap Tes Berbahasa Inggris Toefl. Jurnal SOLMA, 9(1), 143-155. https://doi.org/10.29405/SOLMA.V9I1.4877

Kostin, I. (2004). Exploring Item Characteristics That Are Related To the Difficulty of Toefl Dialogue Items. ETS Research Report Series, 2004(1), i-59. https://doi.org/10.1002/j.2333-8504.2004.tb01938.x

Kuswoyo, H., \& Wahyudin, A. Y. (2017). Improving Student's Listening Skill Using Task- Based Approach in EFL Classroom Setting. 109(Aecon), 118-123. https://doi.org/10.2991/aecon-17.2017.24

Long, M. (2014). Second Language Acquisition and Task-Based Language Teaching (Jhon Wiley (ed.); Jhon Wiley).

Palupi, R. E. A. (2018). TBLT Three Phase Technique dalam Meningkatkan Kemampuan Listening TOEFL Preparation. Jurnal Dimensi Pendidikan Dan Pembelajaran, 6(2), 64-74.

Phillips,

D.

(2001).

[Deborah_Phillips]_Longman_Complete_Course_for_the(BookFi.org).pdf.

Purba, C. N. (2020). Improving Students' Listening Comprehension through New Vocabulary Learning. Budapest International Research and Critics Institute (BIRCIJournal): Humanities and Social Sciences, 3(2), 1270-1279. https://doi.org/10.33258/birci.v3i2.971

Rahbar, S., \& Khodabakhsh, S. (2013). English songs as an effective asset to improve listening comprehension ability; Evidence from Iranian EFL learners. International Journal of Applied Linguistics and English Literature, 2(6), 63-66. https://doi.org/10.7575/aiac.ijalel.v.2n.6p.63

Sari, R., Evianty, R., \& Amran, M. (2019). Listening Skills for Learning German Using Blended Learning Models. Budapest International Research and Critics in Linguistics and Education (BirLE) Journal, 2(4), 616-621. https://doi.org/10.33258/birle.v2i4.659

Stringer, E. T., \& Aragón, A. O. (2020). Action research. Sage publications.

Yulia Nur Ekawati. (2017). Peningkatan Kemampuan Mendengarkan (Listening) Mahasiswa Bahasa Inggris Melalui Model Pembelajaran "Project-Based Learning." Cakrawala: Jurnal Pendidikan, 11(2), 135-143. 